\title{
The Mediation Effects of Customer Satisfaction on the Relations Between Product Price, Service Quality and Purchasing Decision
}

\author{
Hermenegildo de Fatima Carvalho ${ }^{1}$, Estanislau de Sousa Saldanha ${ }^{2}$ and Alvaro Menezes Amaral ${ }^{3}$ \\ Graduate School, Dili Institute of Technology (DIT), Timor-Leste. \\ Email: mancyapane12@gmail.com, estanislausaldanha@yahoo.com, alvaromenezesamaral@gmail.com
}

\begin{abstract}
This research has two main objectives: (1) to examine the effect of price, service quality and customer satisfaction on customer's purchasing decision, (2) to test the mediation effects of the customer satisfaction on the relations between product price and service quality on purchasing decision. Data was collected from 82 insurance company's customers using questionnaire, and hypothesis was tested using Smart- PLS 3.0. The findings reveal that (1) price, service quality and customer satisfaction have direct and significant effect on customer purchasing decision, (2) customer satisfaction has an indirect and significant effect on the relationship between service quality and customer's purchasing decision, and (3) customer satisfaction has no significant effect on the relationship between product price and customer's purchasing decision. The study enriches the existing empirical studies on product price, service quality, customer satisfaction and purchasing decision in emerging market. The study also provides practical implications to service industry managers to enhance customer satisfaction and purchasing decision, ultimately increasing market share and organization profits by considering service quality and product price.
\end{abstract}

Keywords: Price, Service Quality, Customer Satisfaction and Purchase Decision.

\section{Introduction}

In recent competitive business environment, companies are trying to retain their customers; therefore, they offer products/services according to the customer demands (Slater and Narver, 1994; Annamdevula and Bellamkonda, 2016). Furthermore, companies are continually monitoring the level of customer satisfaction (Ginon et al., 2014) in order to keep offering high value creation of products/services to meet customer demand and loyalty (Koutsothanassi, Bouranta, and Psomas, 2017; Sangpikul 2018).

Customer satisfaction is a customer's feelings about the quality of the product/service in accord with their expectation (Parasuraman et al., 1994; Rahman et al., 2017). Therefore, customer satisfaction is an important indicator to determine the success of product/service in the market (Famiyehet al., 2018), leading to enhance customer loyalty (Martín-Consuegra et al., 2007). Customer satisfaction is influenced by the price of the product/service (Steinhauser et al., 2019) and service quality (Chandra et al., 2019). To enhance customer satisfaction and loyalty, companies have to place great emphasis on the service quality (Boonlertvanich, 2019).

Price is the amount of money that is offered to customer in order to get a product/ service (Djatmiko and Pradana, 2016). Price determines the success of product/ service in marketplace, therefore, it should be determined based on customer economic situation which enable them to make decision to purchase (Boniface et al., 2012). The higher the price, likely the less customers to take decision to buy product/service (Kukar-Kinney et al., 2012). A company can continue to exist when a customer decides to purchase a product/service due to a positive sentiment related to that product/service (Akhter, 2009).

Price, quality and image (Cakici et al., 2019), perceive values and quality have great impact on customer purchasing decisions (Weisstein et al., 2017) and customer satisfaction (Martín-Consuegra et al., 2007; Kotler and Keller, 2018). This has been confirmed by numerous empirical studies that purchasing decisions were significantly influenced by price (Kukar-Kinney et al., 2012; Maslowska et al., 2017; Song et al., 2019), service quality, brand loyalty, organization ability to retain brand switching and customer commitment (Papafotikas et al., 2014). However, some empirical studies also revealed that perceived price is negatively influence by consumer intention to buy a product/service (Son and Jin, 2019).

Many empirical studies had been done on the mediation effect of customer satisfaction on service quality and loyalty (Goyal et al., 2013; Boonlertvanich, 2019; Özkan et al., 2019), but there are still limited studies on the effect of service quality, product price on customer purchasing decision through customer satisfaction in service industry in emerging countries. Therefore, it is fruitful to undertake research in these well-known variables in marketing literature in the context of emerging markets. This study aims to: (1) to examine the effect of price, service quality and customer satisfaction on customer's purchasing decision, (2) to test the mediation effects of the customer satisfaction on the relations between product price and service quality on purchasing decision. 


\section{Theoritical Conceptual Frameworks and Hypothesis}

\subsection{Theoretical Frameworks}

\subsubsection{Price}

Price is the amount of money that customers pay to use a product or service (Anderson et al., 2000; Kukar- Kinney et al., 2012; Foster, 2016; Djatmiko and Pradana, 2017). Customers make a payment in return for the product or service that they get (Cakici et al., 2019), therefore, price is an important factor which contributes to the consumers' purchasing decision processes (Son and Jin, 2019).

In general price is divided into two types namely objective price and perceived price. The objective price is the actual price of the product or service, while the perceived price involves the consumer encoding the price and making meaning of it (Beneke and Zimmerman, 2014; Cakici et al., 2019).

According to the equity theory, there is justice between parties (buyers and sellers) who undertake transactions with fair price (Beneke and Zimmerman, 2014). In this regard, buyers evaluating equity or inequity based on a comparison between their own profits or costs and those of other buyers who are in an exchange relationship with the same selling organization for the same product or service (Zietsman et al., 2019). The unfair price may lead to negative implications for companies, including stimulation of buyers' dissatisfactions, which may lead to damaging the exchange relationship. From this, customers may pass negative information to the other customers (Nguyen and Meng, 2016).

Generally Price is influenced by brand name (Chen, Chang, and Chang 2005) and product quality. Perceived quality and customer value will drive up a product or service price (Beneke et al., 2013). Researchers have various views on measuring items for product price. (Cockrill and Goode 2010) suggested using fair and relative price to measure price. In this research, we use fair, price relative to the product, reasonable price, and acceptable price to measure price.

\subsubsection{Service quality}

Service quality is an important factor to create customers value in service industry because it is related to the evaluation of the customer towards a product or service (Zeithaml, 2012). Service quality is the level of difference between a customer's normative expectation about a service and their perception about the actual service delivery by an organization (Parasuraman et al., 1988, 1994). The ultimate measure of quality is whether or not the service lives up to expectations of the customers (Chui et al., 2016). A good service quality will lead customers who have prior experience to generate a positive image of company, resulting in positive preferences (Chien and Chi,
2019), and key source for competitive advantages (Mannan et al., 2019).

Numerous researchers have developed several research scales to measure service quality by combining tangible and intangible dimensions (Carranza et al., 2018). Parasuraman et al. $(1988,1994)$ proposed five dimensions of service quality namely: (1) tangibility (physical facilities, equipment, and appearance of personnel); (2) reliability (ability to perform the promised service dependably and accurately); (3) responsiveness (willingness to help customers and provide prompt service); (4) assurance (knowledge and courtesy of employees and their ability to inspire trust and confidence); and, (5) empathy (caring and individualized attention the firm provides to its customers). However, the dimensions of PZB (1994) have been criticized by Cronin and Taylor (1994) that the service quality (SERVQUAL) only focus on expectation-based component compared to performance-based component. Therefore, the authors proposed service performance (SERVPERF) as reliable scale to measure service quality than SERVQUAL (Ju et al., 2019). Despite this criticism, SERVQUAL is the more widely used in both empirical studies and industrial organization practices in a wide range of industries (Meesala and Paul, 2018).

\subsubsection{Customer satisfaction}

Consumer's satisfaction is the key factor that drives when the performance of the product or service exceeds expectations (Meesala and Paul, 2018). Customer satisfaction is a feeling of pleasure that comes about after comparing the result of a product with the desired performance (Ong et al., 2017; Pedro et al., 2018). Satisfaction is comparison of buyers on rewards and costs of the purchase in relation to the anticipated implications (Delcourt et al., 2013).

For customer-oriented companies, customer satisfaction is the objective and the marketing aim; therefore, companies are willing to pay special attention in satisfying and retaining customers (Cakici et al., 2019). Satisfaction is influenced by service quality, product quality, price, and contextual and personal factors (Chien and Chi, 2019). Satisfaction is considered a descendant of perceived quality and a better predictor of customer loyalty (Boonlertvanich, 2019), and .purchasing decision.

\subsubsection{Purchasing decision}

The consumer comes to the decision based upon the place for purchase, the brand that $\mathrm{h} / \mathrm{she}$ wants, model, quantity, when to buy, how much they are prepared to spend, and other factors. These decisions are given to the market by sharing information about products and service to consumers to make an evaluation (Hanaysha, 2018). Schiffman and Kanuk (2007) says that consumers often seek relevant information that is linked to their needs based 
upon past experience, before seeking sources of information from other people or external sources. In other words, the experience of purchase in the past is considered to be a font of internal information that is used before making a decision. Aside from this, some consumer decisions have a high possibility to integrate the experience of purchase in the past with marketing programs and sources of non-commercial information (Schiffman and Kanuk, 2007).

Numerous empirical studies suggest that consumers try their best to minimize risks in the decisions that they make (Chaipradermsak, 2007). The decision to purchase is the action of a customer to decide to purchase a product or not, based on a range of factors (Kotler ho Keller, 2012: 166-173). The five stages of making a decision are; identifying the problem, seeking information, evaluating performance alternatives, purchasing, then evaluating performance. According to Kotler ho Keller (2012: 188) there are seven types of people that make the decision to purchase, as follows: Inventor or initiator, consumer, influencer, terminator, the person who approves, the person who buys and the gatekeeper.

\subsection{Conceptual Framework}

The conceptual framework of this research was developed from Parasuraman et al. (1994) and Chien and Chi (2019) for service quality and customer satisfaction, price from Kukar-Kinney et al. (2012), Maslowska et al. (2017), Song et al. (2019), Zietsman et al. (2019), and purchasing decision from Huang and Benyoucef (2017) and Hanaysha (2018). From theories and previous empirical studies, we frame our study in the following order: price, service quality, and customer satisfaction are the key factors to improve customer's purchasing decision in a service industry, while customer satisfaction is a better mediator for the relationship between price, service quality and customer purchasing decision. We use deductive and positivism approach to test multivariable relationship based on this conceptual framework by using Smart-PLS 3.0.

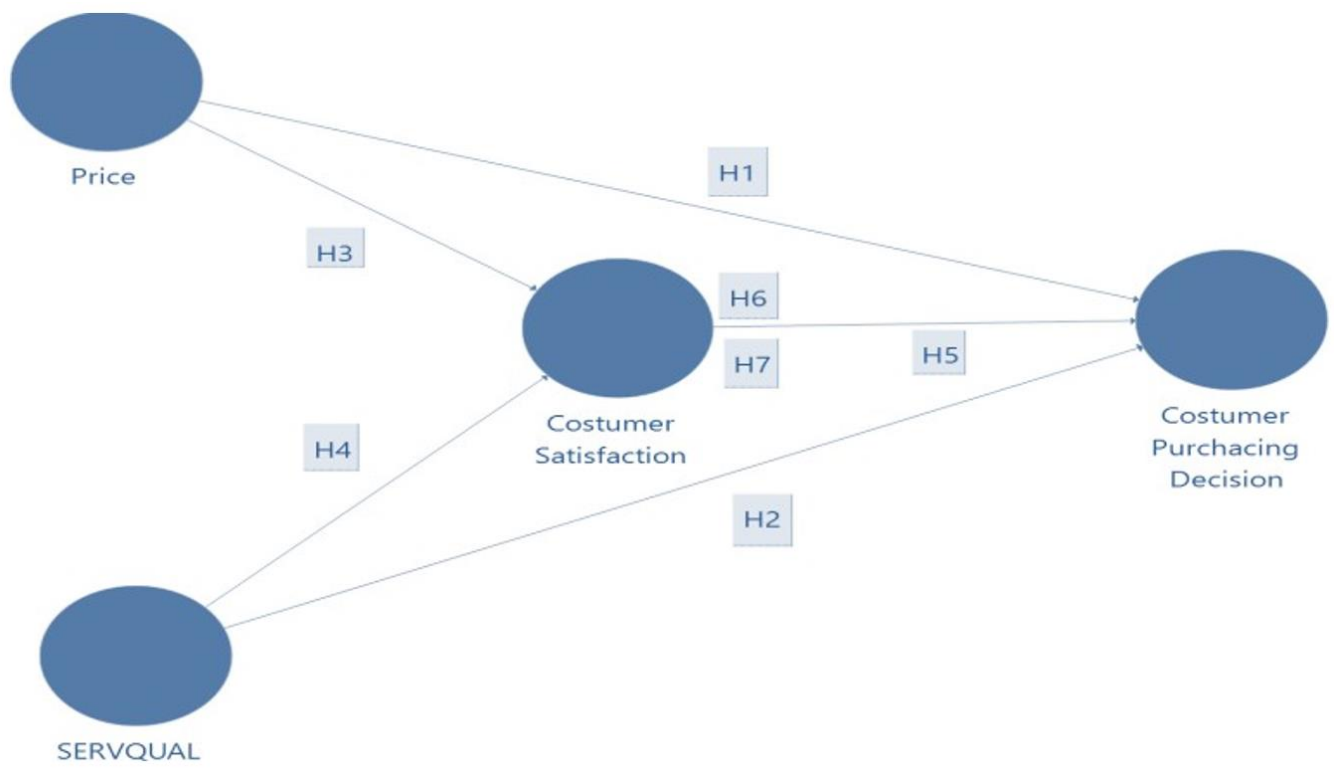

Figure 2.1. Conceptual Research Model and Hypothesis

\subsection{Hypothesis}

Price is a determining factor in customer decisions because customers are sensitive to the product price. When customers are sensitive to quality, then price does not affect their decision (Jung and Yoon, 2012; Ramadan, Farah, and Kassab, 2019; Tata, Prashar, and Gupta, 2020). Numerous empirical studies show that price has positive and significant influence on customer decision to buy (Azzadinaet al., 2012; Djatmiko and Pradana, 2016).
Therefore, we propose the following hypothesis:

$\mathrm{H} 1$ : Price has a positive and insignificant influence on customer's purchasing decision.

Service quality has a positive and significant influence on a customer decision. When service is good, customers feel good and they decide to purchase the goods (Maslowska et al., 2017). Some empirical studies show that fair, acceptable, and reasonable price will have a 
positive and significant influence on the customer decision to buy (Djatmiko and Pradana, 2017). Therefore, we propose the following hypothesis:

$\mathrm{H}$ 2: The service quality has a positive and significant influence on the decision to purchase.

Price is an important factor for customers because a good price can make a customer satisfied enough for them to purchase product or service from that company (Moser, 2016). Price is a determining factor for a customer in making a decision (Steinhauser et al., 2019). Price has positive and direct impact on customer satisfaction (Razak et al., 2017). For this reason, in this study, the hypothesis has been formed as follows:

H3: Price has a positive and significant influence on customer satisfaction.

Service quality is a competitive advantage of a company. A company that has resources and capacity will develop good quality of product and service that is innovative and has value for the customer. Service quality also influences customer satisfaction (Parasuraman et al., 1988; Annamdevula and Bellamkonda, 2016). For this reason, in this study, the study hypothesis can be developed as follows:

$\mathrm{H} 4$ : The service quality has a positive and significant influence on customer satisfaction.

A customer who is satisfied with a product or service of a company has a strong connection with that company. A customer who is satisfied with a product or service can influence the decisions of other customers who purchase a product or service. Many empirical studies show that the service quality has a positive and significant influence on customer satisfaction (Aliman and Mohamad, 2016; Annamdevula and Bellamkonda, 2016; Chien and Chi, 2019). Therefore, we propose the following hypothesis:

H5: Customer satisfaction has a positive and significant influence on the decision to purchase.

Satisfaction is a positive sentiment from a customer towards a product or service of a company. When a customer is satisfied with a product or service, they will purchase that product or service (von Helversen et al., 2018). A satisfied customer also helps in purchasing a product with a reasonable price (Ramadan, Farah, and Kassab, 2019). For this reason, this study proposes the following hypothesis:

H6: Satisfaction has a positive and significant effect on the relationship between price and the decision to purchase.
Satisfaction has an influence on the relationship between service quality and the decision to buy (Weisstein et al., 2017). Service quality helps customers to be satisfied, ultimately making the decision to purchase a product (Anderson, Thomson, and Wynstra, 2000). For this reason, in this study the hypothesis can be formulated as follows:

H7: Satisfaction has a positive and significant effect on the relationship between service quality and the decision to buy.

\section{Research Methods}

The population of this study is customers from insurance company namely Federal Insurance Timor S.A in Dili, Timor-Leste. Data was collected from 82 respondents selected based on the accidental randomized method from the insurance company's listed customers. All measurement items for the constructs of price, service quality, customer satisfaction, and customer purchasing decision were developed using a five-point Likert-type scale for all items in this study, ranging from $1=$ "Strongly Disagree" to $5=$ "Strongly Agree".

Data analysis was carried out using SMART-PLS 3.0 which has been proved to be good for testing multivariate model, small sample size, formative/reflective indicators (Hair et al., 2014) and a rich statistical tool for research in management and strategy areas (Valaei, 2017). We began with designing a conceptual model derived from theoretical and previous empirical studies linking to the research constructs such as product price, service quality, customer satisfaction and customer purchasing decision.

After designing conceptual model, we tested the validity and reliability of the model following the rule of Hair et al. (2014). We used cronbath alpha (CA) and composite reliability (CR) for outer model reliability test, and outer loading (OL) and average variance extracted (AVE) for convergent validity test, and Fornell-Larcker Criterion (FLC) and heterotrait-monotrait (HTMT) for discriminate validity as recommended by Hair et al. (2017) and Henseler et al. (2015) respectively.

The hypothesis test used path coefficient using $\mathrm{T}$ and $\mathrm{P}$ values. The positive and significant relationships of variables were occurred, when the $\mathrm{T}$ values were greater than 1.96 , and $\mathrm{P}$ values were lower than the threshold values of 0.05 (Hair et al., 2017).

\section{Results}

\subsection{Reliability and Validity}

Reliability tests usually use Cronbach's alpha (CA) and composite reliability (CR). According to Hair et al. (2014) the items are reliable when the value of CA is greater than 0.7 and $C R$ is also greater than 0.7. Even so, in exploratory studies, the value of 
$\mathrm{CA}$ and $\mathrm{CR}$ can be greater than 0.6. Table 4.3.1 shows the results of reliability teste in which CA and $\mathrm{CR}$ values are greater than the minimum threshold value of 0.7 , therefore the indicators of all variables are reliable to be used in this model.

Table 4.3.1. Reliability and Validity Test

\begin{tabular}{llll}
\hline Item & CA & CR & AVE \\
\hline Tang. & 0.802 & 0.883 & 0.716 \\
Rel. & 0.816 & 0.891 & 0.731 \\
Emp. & 0.878 & 0.925 & 0.804 \\
Res. & 0.809 & 0.887 & 0.724 \\
Ass. & 0.797 & 0.880 & 0.709 \\
Pri. & 0.981 & 0.986 & 0.946 \\
CS & 0.966 & 0.978 & 0.936 \\
PD & 0.855 & 0.897 & 0.639 \\
\hline
\end{tabular}

There are two types of validity tests namely convergent validity (CV) and discriminant validity (DV). Convergent validity (CV) uses two parameters such as outer loading (OL) and average variance extracted (AVE) (Hair et al., 2017).

The items have a variable validity when the outer loading (OL) value is more than 0.7 and average variance extracted (AVE) value is more than 0.5. Looking at the outer loading (OL) like in Figure 4.1, the value of all the items is larger than 0.7, however the value of PS2 is lower than the variance extracted (AVE) are larger than 0.5 (Table 4.3.1), therefore looking at convergent validity $(\mathrm{CV})$, all the items are valid to use to test the relationship between the variables (inner model).

The discriminant validity (DV) test uses two parameters namely Farnell- Larcker Criterion (FLC) and heterotrait-monotrait (HTMT). According to Hair et al., (2014), the item is valid when the root value average variance extracted (AVE) from the item towards its own item is greater than the root value of other AVE items in the Table. Table 4.3.2 shows that the root value of average

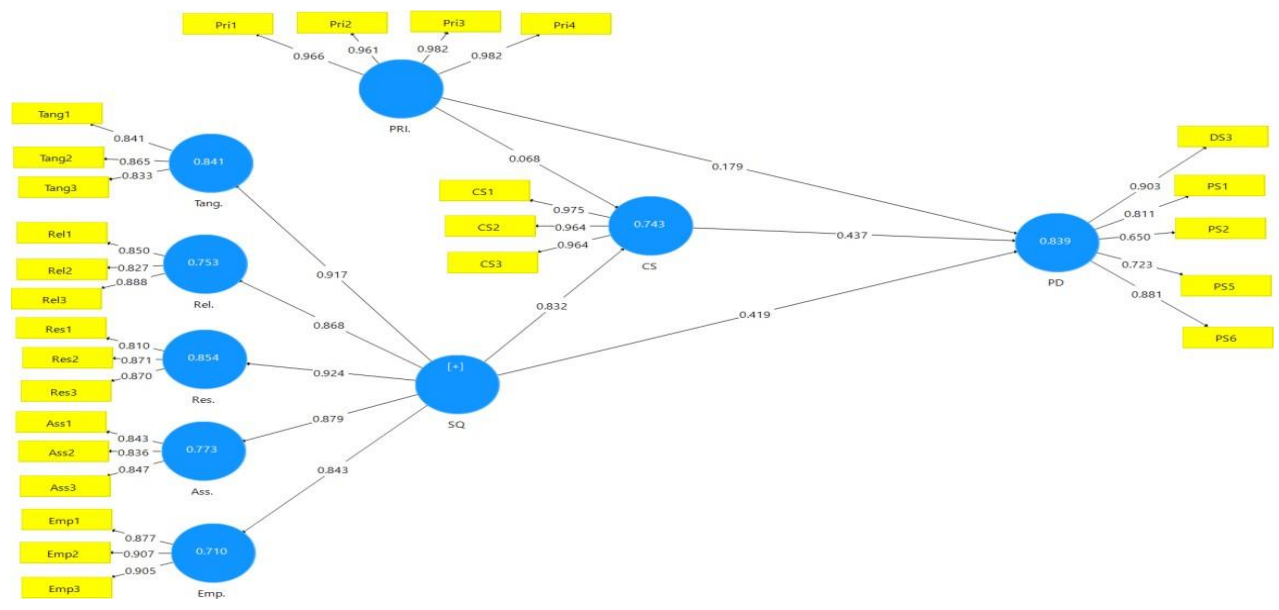

Figure 4.1. Outer Loading for Convergent Validity

threshold value of 0.7. However, according to Hair et al. (2014), the value of outer loading (OL) can still be accepted when the research is categorized as an exploratory research, and the outer loadings does not influence on content validity.

Looking at the value of average variance extracted (AVE), the items in this model with the value of average variance extracted (AVE) towards its own item is larger than the root value of other AVEs. So we can see from Fornell-Larcker Criterion (FLC), the indicators for all variables are valid based on discriminant validity (DV).

The discriminant validity (DV) is also tested using parameter heterotrait- monotrait (HTMT). According to Henseler et al. (2015), the item is valid when the value of heterotrait-monotrait (HTMT) is lower than 0.9. Table 
4.3.3 shows the value of heterotrait-monotrait (HTMT) from all items are lower than 0.9. Therefore, all the indicators are valid according to discriminant validity (DV).

Table 4.3.2. Fornell-Larcker Criterion

\begin{tabular}{ccccccccc}
\hline Item & Ass. & CS & Emp. & PD & PRI. & Rel. & Res. & Tang. \\
\hline Ass. & 0.842 & & & & & & & \\
CS & 0.740 & 0.967 & & & & & & \\
Emp. & 0.676 & 0.670 & 0.896 & & & & & \\
PD & 0.756 & 0.871 & 0.642 & 0.799 & & & & \\
PRI. & 0.280 & 0.410 & 0.310 & 0.530 & 0.973 & & & \\
Rel. & 0.728 & 0.714 & 0.731 & 0.679 & 0.355 & 0.855 & & \\
Res. & 0.791 & 0.781 & 0.761 & 0.795 & 0.329 & 0.775 & 0.851 & \\
Tang. & 0.725 & 0.826 & 0.724 & 0.860 & 0.455 & 0.726 & 0.783 & 0.846 \\
\hline
\end{tabular}

Table 4.3.3. Heterotrait-Monotrait (HTMT)

\begin{tabular}{cccccccc}
\hline Item & Ass. & CS & Emp. & PD & PRI. & Rel. & Res. \\
\hline CS & 0.825 & & & & & & \\
Emp. & 0.784 & 0.725 & & & & & \\
PD & 0.889 & 0.891 & 0.726 & & & & \\
PRI. & 0.315 & 0.418 & 0.328 & 0.589 & & & \\
Rel. & 0.884 & 0.803 & 0.859 & 0.789 & 0.388 & & \\
Res. & 0.890 & 0.881 & 0.900 & 0.873 & 0.363 & 0.885 & \\
Tang. & 0.875 & 0.898 & 0.856 & 0.878 & 0.512 & 0.884 & 0.874 \\
\hline
\end{tabular}

\subsection{Hypothesis Test}

Table 4.4.1 presenting the results of hypothesis test of direct and indirect effects using SMART-PLS 3.0. In regard to the relationship between price (Pri.) and customer purchasing decision (PD), the $\mathrm{T}$ value (2.543) and $P$ value $(0.011)$ which means that the $P$ value is greater than the minimum allowable value of 1.96 and the $P$ value is below than the threshold value of 0.05 (Hair et al., 2017 as cited by Saldanha et al., 2019). Therefore, price has a positive and significant influence on customer purchasing decision as hypothesized by $\mathrm{H}_{1}$. In regard to relations between service quality (SQ) and customer purchasing decision, the $\mathrm{T}$ value (5.001) and the $\mathrm{P}$ value $(0.000)$, therefore, service quality has a positive and significant influence on customer purchasing decision (PD) which is in line with $\mathrm{H}_{2}$. In relationship to price (Pri.) and customer satisfaction $(\mathrm{CS})$, the $\mathrm{T}$ value (1.085) and $\mathrm{P}$ value (0.275) which means the $T$ value is lower than 1.96 and the $P$ value is greater than 0.05 . Therefore, price has a positive and insignificant influence on customer satisfaction (CS), so $\mathrm{H}_{3}$ is rejected.

From the relationship between service quality (SQ) and customer satisfaction (CS), the T value (14.381) and $P$ value $(0.000)$ which means that service quality has a positive and significant influence on customer satisfaction (CS) as hypothesized by $\mathrm{H}_{4}$. In relationship to customer satisfaction (CS) and purchasing decision (PD), the $\mathrm{T}$ value (5.563) and $\mathrm{P}$ value (0.000) which is greater than 1.96 and is lower than 0.05 respectively. Therefore, customer satisfaction has a positive and a significant influence on customer purchasing decision (PD) as hypothesized by $\mathrm{H}_{5}$.

This study also used SMART-PLS 3.0 to test the mediating effect of customer satisfaction in the relationship between price (Pri.), service quality (SQ) and purchasing decision (PD). Table 4.4 shows he results of specific indirect effect (the mediation effect) in regard to price, satisfaction and purchasing decision, the specific indirect $T$ value (1.103) and the $P$ value (0.271) which does not meet the minimum threshold values as suggested by Hair et al. (2014) as cited by Saldanha et al. (2019). Therefore, customer satisfaction has no significant effects on the relationship between price and purchasing decision. which is not in line with H6. Table 4.4 also shows that the result of specific indirect effect of customer 
satisfaction on service quality (SQ) and purchasing decision (PD), the $T$ value (5.693) and $P$ value $(0.000)$ are greater than the threshold values of $T$ and $P$ respectively. Therefore, customer satisfaction has a significant effect on the relationship between service quality (SQ) and purchasing decision (PD) as hypothesized by $\mathrm{H} 7$.

Table 4.4.1. Test Result of Hypothesis (Direct Effect)

\begin{tabular}{ccccccc}
\hline & $\begin{array}{c}\text { Original } \\
\text { Sample } \\
(\mathbf{O})\end{array}$ & $\begin{array}{c}\text { Sample } \\
\text { Mean } \\
(\mathbf{M})\end{array}$ & $\begin{array}{c}\text { Standard } \\
\text { Deviation } \\
(\mathbf{S T D E V})\end{array}$ & $\begin{array}{c}\text { T Statistics } \\
(\mid \mathbf{O} / \text { STDEV })\end{array}$ & $\begin{array}{c}\text { P } \\
\text { Values }\end{array}$ & Hypothesis \\
\hline PRI. => PD & 0.179 & 0.182 & 0.071 & 2.543 & 0.011 & Support \\
\hline SQ $=>$ PD & 0.419 & 0.431 & 0.084 & 5.001 & 0.000 & Support \\
PRI. $=>$ CS & 0.068 & 0.064 & 0.063 & 1.085 & 0.278 & Not support \\
\hline SQ $=>$ CS & 0.832 & 0.829 & 0.058 & 14.381 & 0.000 & Support \\
\hline CS $=>$ PD & 0.437 & 0.420 & 0.079 & 5.563 & 0.000 & Support \\
\hline PRI. $=$ PS $=>$ PD & 0.030 & 0.026 & 0.027 & 1.103 & 0.271 & Not support \\
\hline SQ $=$ CS $=>$ PD & 0.364 & 0.347 & 0.064 & 5.693 & 0.000 & Support \\
\hline
\end{tabular}

\section{Discussions}

The first objective of this study was to test the influence of price on the customer purchasing decision. The results of the study show that price has a positive and significant influence on the customer purchasing decision. A fair, reasonable and acceptable price has great impact on customer purchasing decision reflected by quality, service quality, word of mouth, experience and reputation of the products/services. This result is in line with the previous arguments that if consumer get fair and reasonable price, they will decide to purchase the product/service and recommend to other people via word of mouth promotion (Kukar-Kinney et al., 2012; Ginon et al., 2014). The results of this study also confirms the previous empirical studies (Djatmiko and Pradana, 2017; Jain et al., 2018). Conversely, this study is not in line with the study of Son and Jin (2019) who found that perceived price has a negative impact on customer purchasing decision.

The second objective of this study was to test the influence of service quality on customer purchasing decision. The result of this study shows that service quality has a positive and significant influence on purchasing decision because good service quality can make customer feel comfortable, satisfy and purchase firm's products/services. If a company has good products/services, but poor service quality, it will then lead to discourage customers to purchase. In this study, the significance influence of service quality on the customer's purchasing decision is mainly contributed by company's intangible dimensions such as reliable, responsive and timely (assurance) product or service delivery.

The third objective of this study is to test the relationship between price and customer satisfaction. The study shows that price does not have a significant influence on customer satisfaction because price is not the only determining factor in satisfying customer demand. Often, product/service price is cheap, but poor and unreliable quality can lead to customer satisfaction. A combined good product and service will lead to enhance customer satisfaction, although price is not in line with customer wants (Makanyeza and Chikazhe, 2017; Cakici et al., 2019). This is also enhances by the argument that product quality gains better costumer's perceived value, brand image, and reputation. Therefore, price is not the only factor dictate customer satisfaction (Vera, 2015; Özkan et al., 2019). Another explanation is that if there are limited product/services in the market, customers will have limited options, even though, they don't satisfy with price, but they still buy it. This study confirms previous studies that price is insignificant influenced on customer satisfaction (Papafotikas et al., 2014; Steinhauser et al., 2019). Conversely, this result is not in line with the study of Razak et al. (2017) that price has positive and significant effect on customer satisfaction.

The fourth objective of this study is to test the influence of service quality on customer satisfaction. The result of the study shows that service quality has a positive and significant influence on customer satisfaction because good product, reliable, responsible, safe and empathetic services will make customers feel comfortable and satisfied. If a product/service meets customer's expectations, they will feel satisfied, buy again, and recommend product/service to other customers (Parasuraman et al., 1988; Kaur and Soch, 2018; Correia et al., 2019). Therefore, service quality is the main driver for customer satisfaction (Lien, Cao, and Zhou 2017).This study confirms other studies carried out by Saldanha et al. (2018) in Timor-Leste that service quality had a positive 
and significant influence on customer satisfaction. This study also confirms previous empirical studies (Aliman and Mohamad, 2016; Annamdevula and Bellamkonda, 2016; Chien and Chi, 2019).

The fifth objective of this study was to test the influence of customer satisfaction on the customer purchasing decision. The result of this study shows that customer satisfaction has a positive and significant effect on the purchasing decision. So when a customer is satisfied by product/services, they will decide to buy the products/services. This proves that customer purchasing decision relies heavily on the product/service value creation, and service quality offered by companies matching with customer demands (Huang and Benyoucef 2017; Steinhauser, Janssen, and Hamm 2019). In addition, if customers have positive feeling about a product/service, they will purchase that product/service (Guo et al., 2020). Therefore, customer's positive feelings on a product/service will lead to improve customer purchasing decision (Tata, Prashar, and Gupta 2020).

The sixth objective of this study was to test the mediation effect of customer satisfaction on the relationship between price and customer's purchasing decision. The result of the study shows that customer satisfaction is not significantly mediating the relationship between price and customer's purchasing decision. This shows that customer satisfaction is not able to improve the relationship between price and customer's purchasing decision. This can be explained that customers are more caring on service quality, value creation, and product/service benefits rather than price (Razak, Nirwanto, and Triatmanto, 2017). If customers see the benefits, they will still buy the products/services, although they may not satisfy with the price. This is partly due to there is no similar product/service available in the market. In this regard, customers will buy products/services by ignoring price, their expectation and satisfaction as argued by Papafotikas et al. (2014).

The seventh objective of this study was to test the mediation effect of customer satisfaction on the relationship between service quality and customer purchasing decision. The result shows that customer satisfaction has a significant role to improve the relations between service quality and customer purchasing decision. This study can also confirm the study of von Helversen et al. (2018) who found that service quality is the main predictor for customer satisfaction and purchasing decision. Often customers purchase a product based on good service quality, although product price and quality do not meet their expectation (Taghavi and Seyedsalehi, 2015).

\section{Conclusions and Implications}

Price, service quality, customer satisfaction and purchasing decision are key factors for modern marketing strategy to extend company's market share and business profitability. Therefore, many empirical studies have done to adjust these constructs and their measured items in different industrial setting, types, size and environment in order to support sustainable business operation. Previous empirical studies show that there are no uniformed results on the linkages between these constructs, and this can also be confirmed by this study. As can be seen that price, service quality and customer satisfaction have direct and significant impacts on customers 'purchasing decision in service industry. In addition, customer satisfaction is triggered by service quality, but not the product price. In terms of mediation effects, customer satisfaction plays important role to improve the relationship between service quality and customer purchasing decision, but poor contribution to the relationship between price and customer's purchasing decision.

The study enriches the existing empirical studies on product price, service quality, customer satisfaction and purchasing decision in emerging market. The study also provides practical implications to service industry managers to enhance customer satisfaction and purchasing decision, ultimately increasing market share and organization profits by considering service quality and product price.

\section{Limitations and Future Research}

This study was carried out to test the mediating effect of customer satisfaction on the relationship between price, quality of service, and a customer's purchasing decision, as well as to test the influence of price, service quality and customer satisfaction on customers' decisions. Nonetheless, it is recognized that this study has numerous limitations

(1). The study was only used questionnaire for the data collection adopted fully from previous authors. The questionnaire for data collection instrument which may not fully represent the real data because it relies entirely from the perceived response from the respondents which might provide bias answers. To overcome this limitation, future studies could also use observation, in-depth interviews and focus group discussions to get more information in order to draw comprehensive conclusions. (2). This research was done in insurance company, so, it cannot be generalized to other types of industries. Therefore, further studies need to be carried out in other types of industries leading to make better data generalization. (3). This study only used customer satisfaction as mediating variable, therefore, future researches also need to employ innovation, differentiation strategy, entrepreneurship orientation and market orientation as mediating variables in order to understand customer's behavioral views in regard to their purchasing decision. (4) This study used periodical data 
that has not been able to observe the significance linkages between variables over time. Therefore, longitudinal approaches need to be considered in the future researches.

\section{References}

Akhter, Syed H. 2009. "Niches at the Edges: Price-Value Tradeoff, Consumer Behavior, and Marketing Strategy." Journal of Product and Brand Management 18 (2): 136-42.

Aliman, Nor Khasimah, and Wan Normila Mohamad. 2016. "Linking Service Quality, Patients' Satisfaction and Behavioral Intentions: An Investigation on Private Healthcare in Malaysia." Procedia - Social and Behavioral Sciences 224 (August 2015): 141-48.

Anderson, James C., James B.L. Thomson, and Finn Wynstra. 2000a. "Combining Value and Price to Make Purchase Decisions in Business Markets." International Journal of Research in Marketing 17 (4): 307-29.

2000b. "Combining Value and Price to Make Purchase Decisions in Business Markets." International Journal of Research in Marketing 17: 307-29.

Annamdevula, Subrahmanyam, and Raja Shekhar Bellamkonda. 2016a. "Effect of Student Perceived Service Quality on Student Satisfaction, Loyalty and Motivation in Indian Universities: Development of HiEduQual." Journal of Modelling in Management 11 (2): 488-517.

—. 2016b. "The Effects of Service Quality on Student Loyalty: The Mediating Role of Student Satisfaction." Journal of Modelling in Management 11 (2): 446-62.

Azzadina, Irna, Aulia Nurul Huda, and Corinthias Pamatang Morgana Sianipar. 2012. "Understanding Relationship between Personality Types, Marketing-Mix Factors, and Purchasing Decisions." Procedia - Social and Behavioral Sciences 65 (ICIBSoS): 352-57.

Beneke, Justin, Ryan Flynn, Tamsin Greig, and Melissa Mukaiwa. 2013. "The Influence of Perceived Product Quality, Relative Price and Risk on Customer Value and Willingness to Buy: A Study of Private Label Merchandise.” Journal of Product and Brand Management 22 (3): 218-28.

Beneke, Justin, and Natalia Zimmerman. 2014. "Beyond Private Label Panache: The Effect of Store Image and Perceived Price on Brand Prestige." Journal of Consumer Marketing 31 (4): 301-11.

Boniface, Bonaventure, Amos Gyau, and Randy Stringer. 2012. "Linking Price Satisfaction and Business Performance in Malaysia's Dairy Industry." Asia Pacific Journal of Marketing and Logistics 24 (2): 288-304.

Boonlertvanich, Karin. 2019. "Service Quality, Satisfaction, Trust, and Loyalty: The Moderating Role of Main-Bank and
Wealth Status.” International Journal of Bank Marketing 37 (1): 278-302.

Cakici, A. Celil, Yilmaz Akgunduz, and Oya Yildirim. 2019a. "The Impact of Perceived Price Justice and Satisfaction on Loyalty: The Mediating Effect of Revisit Intention." Tourism Review 74 (3): 443-62.

Cakici, A Celil, Yilmaz Akgunduz, and Oya Yildirim. 2019 b. "The Impact of Perceived Price Justice and Satisfaction on Loyalty: The Mediating Effect of Revisit Intention." Tourism Review 74 (3): 443-62.

Carranza, Rocío, Estrella Díaz, and David Martín-Consuegra. 2018. "The Influence of Quality on Satisfaction and Customer Loyalty with an Importance- Performance Map Analysis: Exploring the Mediating Role of Trust." Journal of Hospitality and Tourism Technology 9 (3): 380-96.

Chandra, Teddy, Layla Hafni, Stefani Chandra, Astri Ayu Purwati, and Jennifer Chandra. 2019. "The Influence of Service Quality, University Image on Student Satisfaction and Student Loyalty." Benchmarking: An International Journal 26 (5): 8.

Chen, Tser Yieth, Pao Long Chang, and Hong Sheng Chang. 2005. "Price, Brand Cues, and Banking Customer Value." International Journal of Bank Marketing 23 (3): 273-91.

Chien, Li Hsien, and Shu Yi Chi. 2019. "Corporate Image as a Mediator between Service Quality and Customer Satisfaction: Difference across Categorized Exhibitors." Heliyon 5 (3).

Chui, Teo Boon, Mohd Shukur bin Ahmad, Faezah binti Ahmad Bassim, and Nurnadirah binti Ahmad Zaimi. 2016. "Evaluation of Service Quality of Private Higher Education Using Service Improvement Matrix." Procedia - Social and Behavioral Sciences 224: 132-40.

Cockrill, Antje, and Mark M.H. Goode. 2010. "Perceived Price Fairness and Price Decay in the DVD Market." Journal of Product and Brand Management 19 (5): 367-74.

Correia Leal, Catarina, and Aristides I. Ferreira. 2019. "Should I Book Another Hotel? The Effects of Sickness and Ethnicity on Customer Brand Loyalty and Positive Word of Mouth." International Journal of Hospitality Management, no. October 2018.

Cronin, J. Joseph, and Steven A. Taylor. 1994. "SERVPERF versus SERVQUAL: Reconciling Performance-Based and Perceptions-Minus-Expectations Measurement of Service Quality.” Journal of Marketing 58 (1): 125.

Delcourt, Cécile, Dwayne D. Gremler, Allard C.r. Van Riel, and Marcel Van Birgelen. 2013. "Effects of Perceived Employee Emotional Competence on Customer Satisfaction and Loyalty: The Mediating Role of Rapport." Journal of Service Management 24 (1): 5-24. 
Djatmiko, Tjahjono, and Rezza Pradana. 2016. "Brand Image and Product Price; Its Impact for Samsung Smartphone Purchasing Decision." Procedia - Social and Behavioral Sciences.

2017. "Do Customer Reviews Drive Purchase Decisions? The Moderating Roles of Review Exposure and Price." Decision Support Systems.

Famiyeh, Samuel, Disraeli Asante-Darko, and Amoako Kwarteng. 2018. "Service Quality, Customer Satisfaction, and Loyalty in the Banking Sector: The Moderating Role of Organizational Culture." International Journal of Quality and Reliability Management 35 (8): 1546-67.

Foster, Ir Bob. 2016. "The Effect of Price and Service Quality on Customer Satisfaction in Mutiara Hotel Bandung." American Research Journal of Humanities and Social Sciences 2016.

Ginon, Emilie, Gastón Ares, Sylvie Issanchou, Lúcia Helena Esteves dos Santos Laboissière, and Rosires Deliza. 2014. "Identifying Motives Underlying Wine Purchase Decisions: Results from an Exploratory Free Listing Task with Burgundy Wine Consumers.” Food Research International 62: 860-67.

Goyal, Anita, Moutusi Maity, Harsandaldeep Kaur, and Harmeen Soch. 2013. "Mediating Roles of Commitment and Corporate Image in the Formation of Customer Loyalty." Journal of Indian Business Research 5 (1): 33-51.

Guo, Junpeng, Xiaopan Wang, and Yi Wu. 2020. "Positive Emotion Bias: Role of Emotional Content from Online Customer Reviews in Purchase Decisions." Journal of Retailing and Consumer Services 52 (July 2019).

Hair, Joe F., Marko Sarstedt, Lucas Hopkins, and Volker G. Kuppelwieser. 2014. "Partial Least Squares Structural Equation Modeling (PLS-SEM).” European Business Review 26 (2): 10621.

Hair, Joe, Carole L. Hollingsworth, Adriane B. Randolph, and Alain Yee Loong Chong. 2017. "An Updated and Expanded Assessment of PLS-SEM in Information Systems Research." Industrial Management \& Data Systems 117 (3): 442-58.

Hair, Joseph F., G. Tomas M. Hult, Christian M. Ringle, and Marko Sarstedt. 2014. Partial Least Squares Structural Equation Modeling (Pls-Sem). London: SAGE Publication LTD.

Hanaysha, Jalal Rajeh. 2018. “An Examination of the Factors Affecting Consumer's Purchase Decision in the Malaysian Retail Market." PSU Research Review 2 (1): 7-23.

Helversen, Bettina von, Katarzyna Abramczuk, Wiesław Kopeć, and Radoslaw Nielek. 2018. "Influence of Consumer Reviews on Online Purchasing Decisions in Older and Younger Adults." Decision Support Systems 113 (March): 1-10.

Henseler, Jörg, Christian M. Ringle, and Marko Sarstedt. 2015. "A New Criterion for Assessing Discriminant Validity in
Variance-Based Structural Equation Modeling." Journal of the Academy of Marketing Science 43 (1): 115-35.

Huang, Zhao, and Morad Benyoucef. 2017. "The Effects of Social Commerce Design on Consumer Purchase Decision-Making: An Empirical Study." Electronic Commerce Research and Applications 25: 40-58.

Jain, Manisha, Anand B. Rao, and Anand Patwardhan. 2018. "Consumer Preference for Labels in the Purchase Decisions of Air Conditioners in India." Energy for Sustainable Development 42: 24-31.

Ju, Yongwook, Ki Joon Back, Youngjoon Choi, and Jin Soo Lee. 2019. "Exploring Airbnb Service Quality Attributes and Their Asymmetric Effects on Customer Satisfaction." International Journal of Hospitality Management 77 (August 2018): 342-52.

Jung, Hyo Sun, and Hye Hyun Yoon. 2012. "Why Do Satisfied Customers Switch? Focus on the Restaurant Patron VarietySeeking Orientation and Purchase Decision Involvement." International Journal of Hospitality Management 31 (3): 875-84.

Kaur, Harsandaldeep, and Harmeen Soch. 2018. "Satisfaction, Trust and Loyalty: Investigating the Mediating Effects of Commitment, Switching Costs and Corporate Image.” Journal of Asia Business Studies 12 (4): 361-80.

Kotler, Philip, and Kevin Lane Keller. 2018. Marketing Management. Essentials of Management for Healthcare Professionals.

Koutsothanassi, Eleni, Nancy Bouranta, and Evangelos Psomas. 2017. "Examining the Relationships among Service Features, Customer Loyalty and Switching Barriers in the Greek Banking Sector." International Journal of Quality and Service Sciences 9 (3/4): 425-40.

Kukar-Kinney, Monika, Nancy M. Ridgway, and Kent B. Monroe. 2012. "The Role of Price in the Behavior and Purchase Decisions of Compulsive Buyers.” Journal of Retailing.

Lien, Che Hui, Yang Cao, and Xing Zhou. 2017. "Service Quality, Satisfaction, Stickiness, and Usage Intentions: An Exploratory Evaluation in the Context of WeChat Services." Computers in Human Behavior 68: 403-10.

Makanyeza, Charles, and Lovemore Chikazhe. 2017. "Mediators of the Relationship between Service Quality and Customer Loyalty: Evidence from the Banking Sector in Zimbabwe." International Journal of Bank Marketing 35 (3): 540-56.

Mannan, Mahafuz, Nusrat Chowdhury, Priodorshine Sarker, and Riasat Amir. 2019. "Modeling Customer Satisfaction and Revisit Intention in Bangladeshi Dining Restaurants." Journal of Modelling in Management 14 (4): 922-47.

Martín-Consuegra, David, Arturo Molina, and Águeda Esteban. 2007. "An Integrated Model of Price, Satisfaction and Loyalty: 
An Empirical Analysis in the Service Sector." Journal of Product and Brand Management 16 (7): 459-68.

Maslowska, Ewa, Edward C. Malthouse, and Vijay Viswanathan. 2017. "Do Customer Reviews Drive Purchase Decisions? The Moderating Roles of Review Exposure and Price." Decision Support Systems.

Meesala, Appalayya, and Justin Paul. 2018. "Service Quality , Consumer Satisfaction and Loyalty in Hospitals : Thinking for the Future.” Journal of Retailing and Consumer Services 40: 261-69.

Moser, Andrea K. 2016. “Consumers' Purchasing Decisions Regarding Environmentally Friendly Products: An Empirical Analysis of German Consumers." Journal of Retailing and Consumer Services 31: 389-97.

Nguyen, Adam, and Juan Gloria Meng. 2016. "How Source of Funds Affects Buyer's Judgments of Price Fairness and Subsequent Response." Journal of Product and Brand Management 25 (7): 710-20.

Ong, Khian Sin, Bang Nguyen, and Sharifah Faridah Syed Alwi. 2017. "Consumer- Based Virtual Brand Personality (CBVBP), Customer Satisfaction and Brand Loyalty in the Online Banking Industry." International Journal of Bank Marketing 35 (3): 37090 .

Özkan, Pınar, Seda Süer, İstem Köymen Keser, and İpek Deveci Kocakoç. 2019. "The Effect of Service Quality and Customer Satisfaction on Customer Loyalty: The Mediation of Perceived Value of Services, Corporate Image, and Corporate Reputation." International Journal of Bank Marketing.

Papafotikas, Iason, Dimitrios Chatzoudes, and Irene Kamenidou. 2014. "Purchase Decisions of Greek Consumers: An Empirical Study." Procedia Economics and Finance 9 (14): 456-65.

Parasuraman, A.;, Valarie A.; Zeithaml, and Leonard L Berry. 1988. "SERVQUAL: A Multiple-Item Scale for Measuring Consumer Perceptions of Service Quality." Retailing: Critical ... 64 (1): 12-40.

Parasuraman, A., Valarie A. Zeithaml, and Leonard L. Berry. 1994. "Alternative Scales for Measuring Service Quality: A Comparative Assessment Based on Psychometric and Diagnostic Criteria.” Journal of Retailing 70 (3): 201-30.

Pedro, Eugénia de Matos, Helena Alves, and João Leitão. 2018. "Does the Quality of Academic Life Mediate the Satisfaction, Loyalty and Recommendation of HEI Students?" International Journal of Educational Management 32 (5): 881-900.

Rahman, Muhammad Sabbir, Hasliza Hassan, Aahad OsmanGani, Fadi Abdel Muniem Abdel Fattah, and Md Aftab Anwar. 2017. 'Edu-Tourist's Perceived Service Quality and Perception the Mediating Role of Satisfaction from Foreign Students' Perspectives." Tourism Review 72 (2): 156-70.
Ramadan, Zahy B., Maya F. Farah, and Danielle Kassab. 2019. “Amazon's Approach to Consumers' Usage of the Dash Button and Its Effect on Purchase Decision Involvement in the U.S. Market." Journal of Retailing and Consumer Services 47 (January 2018): 133-39.

Razak, Ismail, Nazief Nirwanto, and Boge Triatmanto. 2017. "The Impact of Product Quality and Price on Customer Satisfaction with the Mediator of Customer Value Ismail." Journal of Marketing and Consumer Research 3 (11): 1240-48.

Saldanha, Estanislau de Sousa, I Ketut Rahyuda, Ni Nyoman Kerti Yasa, and I Putu G Sukaatmadja. 2019a. Persaingan Industri, Strategi Bisnis, Dan Kinerja Industri: Studi Pada Industri Jasa Pendidikan Tinggi. Denpasar: Udayana University Press.

Saldanha, Estanislau de Sousa, I Ketut Rahyuda, Ni Nyoman Kerti Yasa, and I Putu Gde Sukaatmadja. 2018. "The Role of Business Strategy in Mediating the Relationship Between Industrial Competition and Performances : A Study in the Higher Education Industry in Timor-Leste." European Jorunal of Business and Management 10 (8): 152-72.

Saldanha, Estanislau de Sousa, I Ketut Rahyuda, Ny Nyoman Kerti Yasa, and I Putu Gde Sukaatmadja. 2019b. "Industrial Competition, Hybrid Strategy and Industrial Performance: Study in Higher Education Industry in Timor-Leste." Journal of Engineering and Applied Sciences 14 (8): 2456-64.

Sangpikul, Aswin. 2018. "The Effects of Travel Experience Dimensions on Tourist Satisfaction and Destination Loyalty: The Case of an Island Destination.” International Journal of Culture, Tourism, and Hospitality Research 12 (1): 106-23.

Slater, Stanley F., and John C. Narver. 1994. "Does Competitive Environment Moderate the Market Orientation-Performance Relationship ?" Journal of Marketing 58 (1): 46-55.

Son, Junghwa, and Byoungho Ellie Jin. 2019. "When Do High Prices Lead to Purchase Intention? Testing Two Layers of Moderation Effects." Asia Pacific Journal of Marketing and Logistics 31 (5): 1516-31.

Song, Myungkeun, Won Seok Lee, and Joonho Moon. 2019. "Exploring Effective Price Presentation Format to Reduce Decision Difficulty and Increase Decision Satisfaction." Tourism Management Perspectives.

Steinhauser, Johann, M. Janssen, and Ulrich Hamm. 2019. "Consumers' Purchase Decisions for Products with Nutrition and Health Claims: What Role Do Product Category and Gaze Duration on Claims Play?" Appetite 141 (June).

Taghavi, Mahsa Sadat, and Alireza Seyedsalehi. 2015. "The Effect of Packaging and Brand on Children's and Parents' Purchasing Decisions and the Moderating Role of Pester Power." British Food Journal 117 (8): 2017-38.

Tata, Sai Vijay, Sanjeev Prashar, and Sumeet Gupta. 2020. "An Examination of the Role of Review Valence and Review Source 
in Varying Consumption Contexts on Purchase Decision.” Journal of Retailing and Consumer Services 52.

Valaei, Naser. 2017. “Organizational Structure, Sense Making Activities, and SMEs' Competitiveness: An Application of Confirmatory Tetrad Analysis-Partial Least Squares (CTAPLS)." VINE Journal of Information and Knowledge Management Systems 47 (1).

Vera, Jorge. 2015. "Perceived Brand Quality as a Way to Superior Customer Perceived Value Crossing by Moderating Effects." Journal of Product and Brand Management 24 (2): 147-56.
Weisstein, Fei L., Lei Song, Peter Andersen, and Ying Zhu. 2017. "Examining Impacts of Negative Reviews and Purchase Goals on Consumer Purchase Decision." Journal of Retailing and Consumer Services 39 (July): 201-7.

Zeithaml, Valarie A. 2012. "Of Consumer Perceptions A MeansEnd Value : Quality and Model Synthesis of Evidence" 52 (3): 222.

Zietsman, Mariëtte Louise, Pierre Mostert, and Göran Svensson. 2019. "Perceived Price and Service Quality as Mediators between Price Fairness and Perceived Value in Business Banking Relationships: A Micro-Enterprise Perspective." International Journal of Bank Marketing 37 (1): 2-19.

\section{Appendix: Data Collection Instrumen}

1= Strongly Disagree; $2=$ Disagree $; 3=$ Netral $; 4=$ Agree $; 5=$ Strongly Agree

\begin{tabular}{|c|c|c|c|c|c|c|}
\hline 1 & Price & 1 & 2 & 3 & 4 & 5 \\
\hline Pri1 & I paid a fair price for the insurance policy & & & & & \\
\hline Pri2 & I consider the insurance pricing policy relative & & & & & \\
\hline Pri3 & I consider the insurance pricing policy is reasonable & & & & & \\
\hline Pri4 & I consider the insurance pricing policy as acceptable & & & & & \\
\hline 2 & Service Quality & 1 & 2 & 3 & 4 & 5 \\
\hline 2.1 & Tangibility & & & & & \\
\hline Tanj1 & $\begin{array}{l}\text { When customers have problems, the company is } \\
\text { sympathetic and reassuring }\end{array}$ & & & & & \\
\hline Tang2 & $\begin{array}{l}\text { The facilities offered by the company are usually } \\
\text { appealing }\end{array}$ & & & & & \\
\hline Tang3 & $\begin{array}{l}\text { Employees at the company are always well dressed and } \\
\text { look tidy }\end{array}$ & & & & & \\
\hline 2.2 . & Reliability & 1 & 2 & 3 & 4 & 5 \\
\hline Rel1 & $\begin{array}{l}\text { Employees of the company are always willing to help } \\
\text { customers when customers have problems }\end{array}$ & & & & & \\
\hline Rel2 & $\begin{array}{l}\text { Employees of the company provide their services at the } \\
\text { time they promised to do }\end{array}$ & & & & & \\
\hline Rel3 & $\begin{array}{l}\text { The company provides accurate information and services } \\
\text { as they promised }\end{array}$ & & & & & \\
\hline 2.3 . & Responsiveness & 1 & 2 & 3 & 4 & 5 \\
\hline Res1 & $\begin{array}{l}\text { Employees in the company tell customers exactly when } \\
\text { services will be performed }\end{array}$ & & & & & \\
\hline Res2 & Employees of the company always willing to help the customers & & & & & \\
\hline Res3 & $\begin{array}{l}\text { The employees in the company give prompt service to } \\
\text { customers }\end{array}$ & & & & & \\
\hline 2.4. & Assurance & 1 & 2 & 3 & 4 & 5 \\
\hline
\end{tabular}




\begin{tabular}{|c|l|c|c|c|c|}
\hline Ass1 & $\begin{array}{l}\text { Employees in the knowledge to answer customers } \\
\text { questions }\end{array}$ & & & & \\
\hline Ass2 & $\begin{array}{l}\text { Employees of the company are courteous with the } \\
\text { customers }\end{array}$ & & & & \\
\hline Ass3 & Customers feel safe when dealing with the company & & & & $\mathbf{1}$ \\
\hline 2.5. & Empathy & $\mathbf{2}$ & $\mathbf{3}$ & $\mathbf{4}$ & $\mathbf{5}$ \\
\hline Emp1 & Company staff give customer personal attention & & & \\
\hline Emp2 & The company places the customers best interest at heart & & & \\
\hline Emp3 & $\begin{array}{l}\text { Employees in the company value respect and individual } \\
\text { attention }\end{array}$ & & & \\
\hline
\end{tabular}

\begin{tabular}{|c|c|c|c|c|c|c|}
\hline 3 & Customer Satisfaction & 1 & 2 & 3 & 4 & 5 \\
\hline CS1 & $\begin{array}{l}\text { I am satisfied with the overall services provided by the } \\
\text { company }\end{array}$ & & & & & \\
\hline CS2 & $\begin{array}{l}\text { I am satisfied with the way I treat in by the company } \\
\text { employees }\end{array}$ & & & & & \\
\hline CS3 & $\begin{array}{l}\text { I am satisfied with the information and services provided } \\
\text { by the employees of the company }\end{array}$ & & & & & \\
\hline 4 & Purchase Decision & 1 & 2 & 3 & 4 & 5 \\
\hline PS1 & $\begin{array}{l}\text { I decided to buy a policy from Federal Insurance Timor } \\
\text { based on product }\end{array}$ & & & & & \\
\hline PS2 & $\begin{array}{l}\text { I decided to buy a policy from Federal Insurance Timor based } \\
\text { on premium. }\end{array}$ & & & & & \\
\hline PS3/DS3 & $\begin{array}{l}\text { I decided to buy a policy from Federal Insurance Timor } \\
\text { based on service quality }\end{array}$ & & & & & \\
\hline PS4 & $\begin{array}{l}\text { I decided to buy a policy from Federal Insurance Timor } \\
\text { based on word of mouth }\end{array}$ & & & & & \\
\hline PS5 & $\begin{array}{l}\text { I decided to buy a policy from Federal Insurance Timor } \\
\text { based on experience }\end{array}$ & & & & & \\
\hline PS6 & $\begin{array}{l}\text { I decided to buy a policy from Federal Insurance Timor } \\
\text { based on Reputation }\end{array}$ & & & & & \\
\hline
\end{tabular}

